Check for updates

The BMJ

Cite this as: BMJ2020;369:m2573 http://dx.doi.org/10.1136/bmj.m2573 Published: 25 June 2020

\section{Covid-19: MPs reject calls to routinely test health and care workers}

\section{Elisabeth Mahase}

MPs have rejected a motion calling for NHS and social care staff to be routinely tested for covid-19 regardless of symptoms, as the country emerges from lockdown.

The motion, proposed by Labour's shadow health secretary, Jonathan Ashworth, fell with 344 votes cast against and 198 for. However, this was not before an amendment on the motion, put forward by the prime minister, Boris Johnson, and health secretary for England, Matt Hancock, was passed, which praised the government for its "tireless efforts."

Despite rejecting the motion the government said it would introduce "regular surveillance testing of staff" on at least a fortnightly basis, although it did not provide further detail on how this would work.

Speaking in the House of Commons on 24 June, Ashworth called on the government to remove the private companies running the NHS Test and Trace service call centres and put local public health officials and GPs in charge instead. He said, "We believe it is time for the government to invest in public health services, put GPs in the driving seat of testing, to give local authorities the localised data that they need, and to begin routine testing of all NHS staff whether symptomatic or not."

Ashworth also pointed to an article written by the former Conservative health secretary Jeremy Hunt, in which he said, "We must commit to weekly tests of NHS staff to prevent a second spike."1

During the early months of the pandemic NHS staff were unable to get tested, meaning many may have had to self isolate unnecessarily and were unable to work. However, as testing capacity was built up, they were prioritised for testing if they showed symptoms.

Ashworth said, "We accept and understand that ministers will have made mistakes throughout this crisis; it was an unprecedented pandemic. But ministers have been slow, their response has been disorganised, the scale and nature of the pandemic, even though it was at the top of the risk register, has at times been underestimated.

"But ministers can learn from their mistakes. They can take the advice of the former health secretary, they can start putting in place a programme for mass testing starting with NHS staff, because we need it for our national health service."

The motion called on the government to "implement a routine weekly testing programme for all NHS and social care staff to enable NHS services to safely resume and ensure the continuity of services throughout the winter alongside a functional, national, public test, trace and isolate system.”

In response, the minister for care, Helen Whately, said that NHS staff with symptoms would continue to be prioritised for testing and that there would be extra testing for staff without symptoms where there was an incident or outbreak, or high prevalence, as well as regular surveillance testing of staff. She said, "On the advice of our chief medical officer, this will be fortnightly or more frequently depending on local or national epidemiology."

Hunt J. We must commit to weekly tests of NHS staff to prevent a second spike. Telegraph. 24Jun 2020. https://www.telegraph.co.uk/news/2020/06/24/mustcommit-weekly-tests-nhs-staff-prevent-second-spike.

This article is made freely available for use in accordance with BMJ's website terms and conditions for the duration of the covid-19 pandemic or until otherwise determined by BMJ. You may use, download and print the article for any lawful, non-commercial purpose (including text and data mining) provided that all copyright notices and trade marks are retained. 